\title{
Supplemental Figures:
}

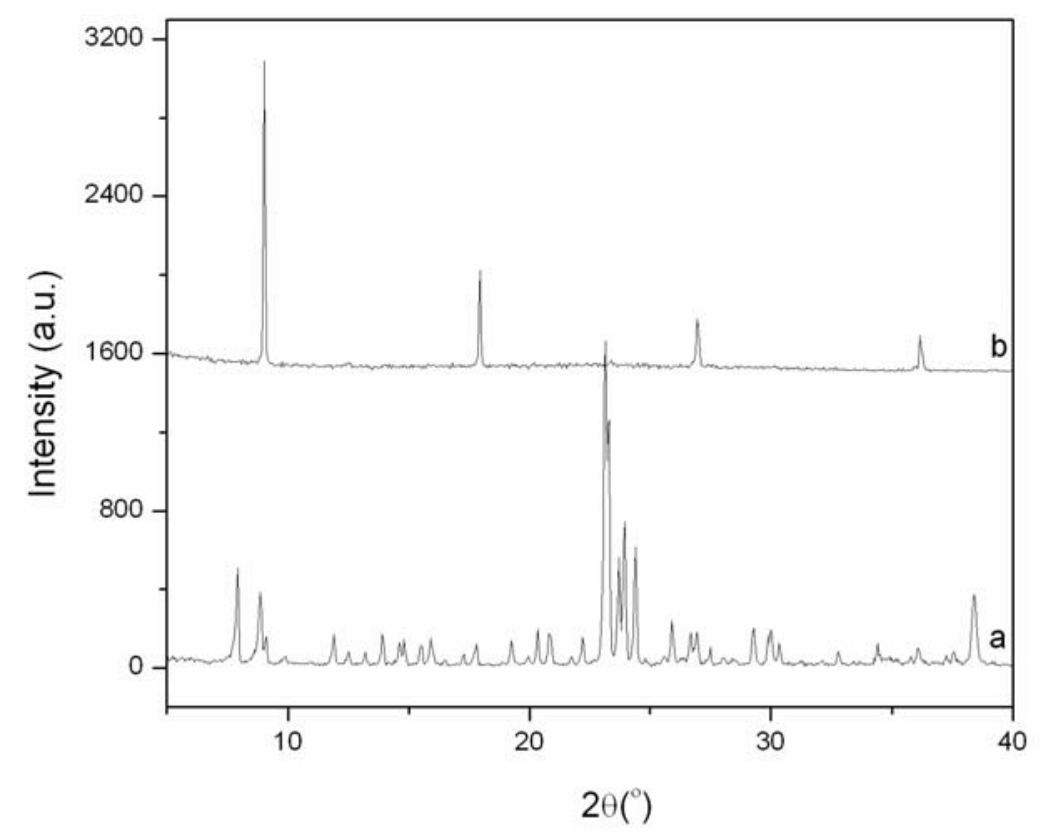

Figure S-1. XRD patterns of (a) pure-silica-zeolite MFI bulk powder and (b) $b$ oriented pure-silica-zeolite MFI monolayer film. 